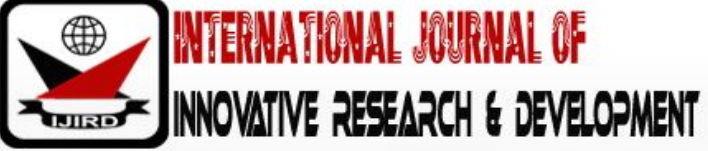

ISSN 2278 - 0211 (Online)

\section{Mining Benefit Management for Sustainable Development}

\author{
La Ode Alwi
Lecturer, Department of Agribusiness, Halu Oleo University, Kendari, Indonesia
R. Marsuki Iswandi
Lecturer, Department of Agribusiness Department, Halu Oleo University, Kendari, Indonesia
Iskandar Zainuddin Rela
Lecturer, Department of Extension Department, Halu Oleo University, Kendari, Indonesia
}

\begin{abstract}
:
The mining sector should be managed optimally from social, economic and ecological aspects. Region with mining areas should innovate in mining benefits management to achieve sustainable development. This research aims are: (1) to determine key indicators in mining benefit management to achieve sustainable development; (2) to determine the role and function of stakeholders in sustainable mining management; and (3) to formulate a mechanism of sustainable development with benefit transfer orientation.

The study was conducted in Bombana District, Southeast Sulawesi Province, Indonesia from April to July 2018. It used to be secondary and primary data. Primary data was obtained through Focused Group Discussion (FGD). Data was analyzed by Interpretative Structural Modeling (ISM) and descriptive analysis.

The research results were follows. First, local regulations were needed to regulate the mining benefits not used as a routine development budget but as endowments fund. Second, the reinforcement was required in mining benefits management, starting from production supervision, production cost and sales through mining benefit agencies. Third, the stakeholder's involvement was needed, namely local government / local board, mining companies, NGOs, universities and communities with each roles and functions
\end{abstract}

Keywords: Benefit mining, sustainable development

\section{Introduction}

\subsection{Background}

Mining sector has large contribution to regional economic growth. Mining boom in one region will increase the economic activity (Iswandi, 2014). Mining businesses contribute to country income through taxes and royalties. State can use the revenue for regional development funds. Other contribution of mining business is Corporate Social Responsibility (CSR) for community, especially those within mining ring area (Alwi, 2016; Iswandi, 2017 and Iskandar et al. 2020). Ideally, mining business contribution can become positive and reduce social problems such as decreasing unemployment and poverty, especially in areas with mining potential. Therefore, mining existence in a region is a blessing. It has contributed to solve social and economic problems in the region.

Beyond the positive contribution, mining management can also create very complex problems. Auty (2003); Hampreys (2007) and Collier (2010) argued that mining existence in a region not only gives blessings but also a resources curse for regions that rely on mining sector as the driving force of their economy. Resources curse is characterized by high environmental degradation and pollution due to mining activities. Fauzi (2010) and Burke (2010) stated that management of non renewable resources, especially mineral mining, often causes externalities, resulting in higher recovery costs. MacMohan et al. (2000) in Iswandi (2017) said that cost of environmental mitigation in Indonesia from mining reaches US $\$ 0.5$ billion per year. Meanwhile, Fauzi (2014) said the cost of environmental degradation varies between US $\$ 0.56$ billion to US $\$ 7.7$ billion per year. It consists of various types of degradation, as water salinity, air pollution and land degradation. On other hand, capitalist system considers human beings and natural resources as a means to achieve their life purpose. Materialistic sizes are the main targets for capitalist. This understanding has spread around the world including in Indonesia. Budiati (2012); Rustiadi et al. (2011) and Jing et al. (2005) in Alwi et al. (2016) said that the impact of capitalism leads to welfare and incomes gaps with the implications to erosion of environment life to become not harmony.

The resource curse phenomenon is not always happened. Some countries as Norway, Alaska, Botswana, Kazakhtan, Azerbaijan and Sao Tome and Principe show a success in mining resources management and provide intergenerational welfare and justice (Sachs et al., 2001; and Frankel, 2012). The steps were taken by some countries to make the income source from non-renewable natural resources as a stability fund and not used as a routine development budget but used as strategic investments. The fund was known as the Natural Resource Fund (NRF) with the purpose to anticipate the resource curse. 
Considering the success experience of several countries in mining management and the support of Indonesian legislation, it was needed an innovation and restructuring of mining benefit management. Similarly, Bombana regency as one of areas having gold mining potential requires good mining benefit management toward sustainable development.

\subsection{Problem}

This research has three issues. First, what were key indicators in mining benefits management to achieve sustainable development. Second, how were the role and function of stakeholders in sustainable mining management. Third, how a beneficiary transfer mechanism was oriented to sustainable development.

\subsection{Objectives}

This research has three objectives. First is to determine the key indicators in mining benefits management to achieve sustainable development. Second is to determine the role and function of stakeholders in sustainable mining management. Third is to formulate a transfer-benefit mechanism with sustainable development orientation.

\section{Research Methods}

\subsection{Research Location and Time}

The research location was Bombana District, Southeast Sulawesi Province, Indonesia. The study was conducted from April to July 2018.

\subsection{Data Collection Technique}

This research uses secondary and primary data. Secondary data were obtained from various related institutions. Primary data were obtained through Focused Group Discussion (FGD). The FGD participants were representatives from Regional Planning and Development Agency, Regional Environment Agency, Department of Energy and Mineral Resources, Forestry Service, and Agriculture and Plantation Agency (at Southeast Sulawesi Province and Bombana District level), academics, mining entrepreneurs, non-governmental organizations (NGOs), and community leaders.

\subsection{The Observed Parameters}

The observed parameters relate to key indicators in mining benefit management to achieve sustainable development, i.e. attributes based on FGD stakeholders' perceptions. The parameters of each attributes and parameters were given score 1 (bad), 2 (good enough), 3 (good) and 4 (very good) categories.

\subsection{Data Analysis}

Reliability matrix through Interpretative Structural Modeling (ISM) was used to analyze data to determine the key indicators attributes in mining benefit management. Safitri et al. (2014) said that ISM analysis score $=1$ if there are more than half the number of respondents said the parameter to $i$ has contextual relationship with parameter to $j$, the opposite has score 0 . Meanwhile, descriptive analyse was used to determine the role and functionality of stakeholder in relation with mining benefit and benefit transfer mechanism.

\section{Discussion}

\subsection{Key Indicators of Mining Benefit Management}

Key indicators of mining benefit management were variables to support sustainable development. These indicators were an institutional strength in mining management. Good institutionalization was the mechanism that conforms to a commonly agreed, transparent, effective and responsive organization procedure for public interest. Sulistyani (2004) said that to achieve a welfare rationalization related to mining management with sustainable development orientation was absolutely need responsive management for public interest. Good management was characterized by a credible commitment to institutional goals (Williamson, 2000). In accordance with FGD results and Iswandi, et al (2018), 12 key indicators of mining benefit management for sustainable regional development (were identified in Table 1. 


\begin{tabular}{|c|c|c|}
\hline No & Key Indicators & Description \\
\hline 1. & $\begin{array}{c}\text { Utilization of effective mining } \\
\text { benefits }\end{array}$ & $\begin{array}{c}\text { Effective and useful mining benefit } \\
\text { management }\end{array}$ \\
\hline 2. & Financial flow & $\begin{array}{l}\text { The flow pattern in accordance with } \\
\text { applicable mechanism or regulation }\end{array}$ \\
\hline 3. & Production Supervision & $\begin{array}{l}\text { Ensuring the level of gold produced in every } \\
\text { production process by company }\end{array}$ \\
\hline 4. & External supervision & $\begin{array}{l}\text { Mining benefits managed by a particular } \\
\text { institution (stand alone) should be audited by } \\
\text { an external party (Financial Auditing Agency) }\end{array}$ \\
\hline 5. & $\begin{array}{l}\text { Mining benefit management } \\
\text { bodies }\end{array}$ & $\begin{array}{c}\text { Availability of individual institutions in } \\
\text { mining benefits management }\end{array}$ \\
\hline 6 & $\begin{array}{l}\text { Investment placement } \\
\text { committees }\end{array}$ & $\begin{array}{c}\text { Maintaining the continuity to fulfil short term } \\
\text { obligations (liquidity) and long term } \\
\text { (solvency) and profit }\end{array}$ \\
\hline 7. & $\begin{array}{l}\text { Availability of multi-stakeholder } \\
\text { human resources }\end{array}$ & $\begin{array}{l}\text { The importance of high-quality human } \\
\text { resources to manage the mining benefits from } \\
\text { multi parties }\end{array}$ \\
\hline 8. & $\begin{array}{c}\text { Regulation availability (Local } \\
\text { Regulation) }\end{array}$ & $\begin{array}{l}\text { Local Regulation is needed to regulate mining } \\
\text { benefit as local perennial or generation fund }\end{array}$ \\
\hline 9. & Availability of mining benefits & $\begin{array}{l}\text { Available funds through corporate taxes and } \\
\text { royalty / land rent payments during mining } \\
\text { process activities }\end{array}$ \\
\hline 10 & $\begin{array}{l}\text { Social impact (lower social } \\
\text { conflict) }\end{array}$ & $\begin{array}{l}\text { Conflict minimization from mining } \\
\text { management }\end{array}$ \\
\hline 11. & $\begin{array}{l}\text { Economic impacts (increasing the } \\
\text { regional economic revenues) }\end{array}$ & $\begin{array}{l}\text { Increasing the community income and } \\
\text { Domestic Product Bruto in Bombana District }\end{array}$ \\
\hline 12. & $\begin{array}{l}\text { Ecological/ environmental } \\
\text { impacts (no degradation and } \\
\text { pollution) }\end{array}$ & $\begin{array}{c}\text { The availability of internal supervisors to } \\
\text { oversee the performance of mining benefit } \\
\text { management bodies }\end{array}$ \\
\hline
\end{tabular}

Table 1: Key Indicators of Mining Management with Sustainable Development Orientation

ISM analysis produces Structural Model Charts from key indicators as shown in Figure 1

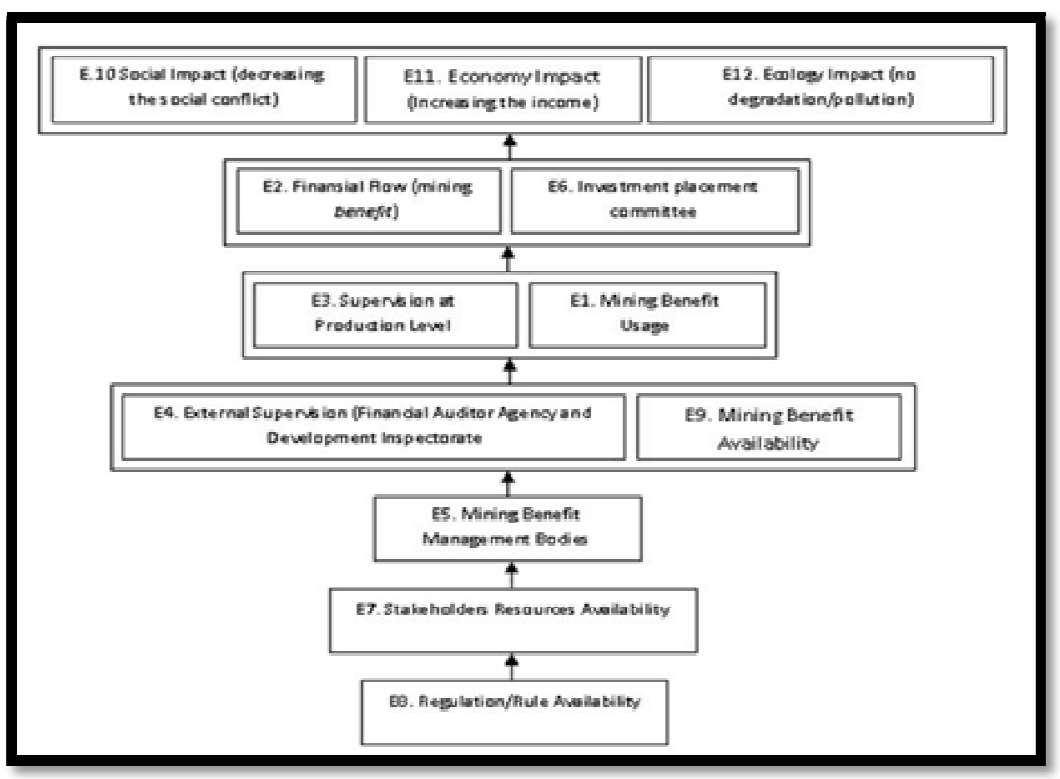

Figure 1: ISM Model Diagram from Mining Benefit Management

\subsection{Stakeholders Role in Mining Benefit Management for Sustainable Development Orientation}

Research results found five stakeholders of mining benefit management. They are: (1) Local Government, (2) Mining companies, (3) Non-governmental organizations (4) Universities and (5) communities. Each stakeholder has roles and functions as presented in Table 2. Williamson (2000), Shultz (2004), Stiglitz (2007), Dharmawan (2010), Yustika (2012) and Iskandar (2018) stated that stakeholder involvement in public institutions can decrease the monopolistic attitudes of renter and ruler because of mutual supervision from each other. 


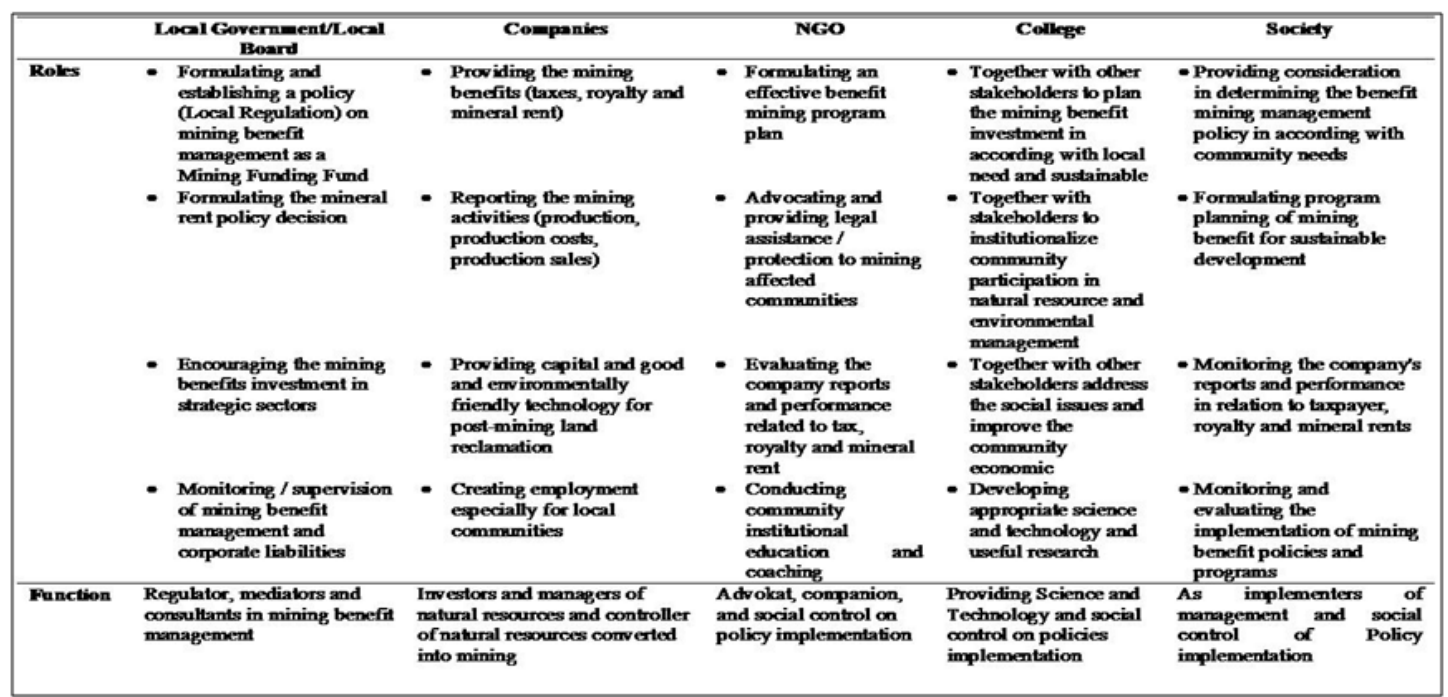

Table 2: Roles and Unctions of Stakeholders in Mining Benefits Management

The mining companies pay mining benefits in form of taxes and royalties to government and mineral rent as the repayment value of capital services disrupted by gold mining activities. The mining benefits should be used as a mining endowment managed by independent institutions such as the Investment Committee to determine the amount of endowment funds for strategic investment objectives, spillover effects and as a solidarity fund. The mining benefits management should be monitored, audited and validated by state auditor as Development and Financial Examiner and Regional Inspectorate. Therefore, the mining benefits derived from mineral rent, taxes and royalties can be set aside as long-term endowments. The mining benefit management mechanism is shown in Figure 2.

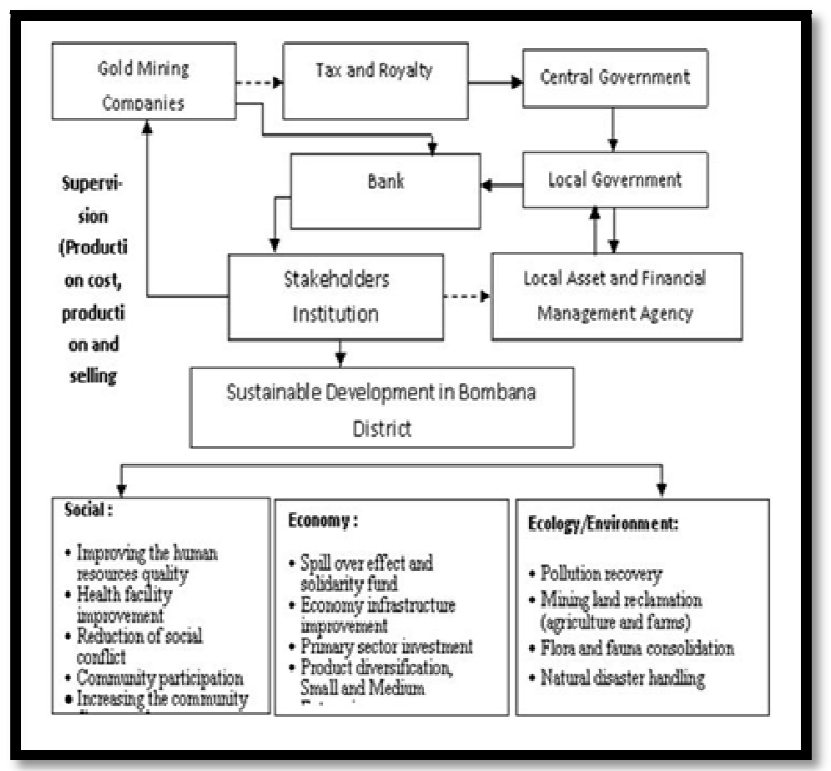

Figure 2: Mining Benefit Management Mechanism

\section{Conclusion}

Local regulations is needed to regulates the mining benefits not used as a routine development budget but as endowments fund that serve as: (a) cushion instruments due to economic shocks from mining sector; (b) a catalyst to transform from mining to non-mining sector; (c) alternative funding mechanism for regional development; and (d) reserve funds to reduce the burden of mining companies on environmental restoration.

The reinforcement is needed in mining benefits management, starting from production supervision, production cost and sales through mining benefit agencies.

The stakeholder's involvement is needed, namely local government / local board, mining companies, NGOs, universities and communities with each roles and functions.

\section{Acknowledgment}

The author is aware of the fact that this paper " Mining Benefit Management for Sustainable Development" can grow well, due to the assistance of several parties. Therefore the author thanks to: Dr. La Aba, S.Si., M.Si, as the Head of the Halu Oleo University Research and Community Service Institute, has granted permission to carry out collaborative research with the Regional Government of Southeast Sulawesi Province. 
Dr. Ir. Lukman Yunus, M.Si, sincerely sincerely provides input and corrects this paper until it becomes a journal draft and even becomes a journal

Dr. Ir. Sukamto Toding, M.Si, as the Head of the Regional Research and Development Agency for Southeast Sulawesi Province, has facilitated research activities and provided important data related to this writing.

\section{References}

i. Alwi, L. O., A. H. Dharmawan, A. Fauzi and P. M. Hutagaol, 2016.Mineral Fund and Regional Sustainable Developmen (Case Studi of Bombana Regency, Southeast Sulawesi Province). Australian Journal of Basic and Applied Science, 10 (6) March 2016, Page: 127-134. ISSN: 1991-8178 ; EISSN: 2309-8414.

ii. Alwi, L. O., A. H. Dharmawan, A. Fauzi, dan P. M. Hutagaol, 2016,Tata Kelola Kelembagaan Mineral Fund Dalam Menunjang Pembangunan Berkelanjutan: Studi Kasus Kabupaten Bombana Provinsi Sulawesi Tenggara. Jurnal Ekonomi dan Kebijakan Publik, Vol. 7, No. 1 Juni 2016. Hal. 29-42.

iii. Auty, M. R., 2003. Sustaining Development In Mineral Economies : The Resouces Curse. Thesis, Routlegde, London.

iv. Budiati L., 2012. Good Governace Dalam Pengelolaan Lingkungan Hidup. Ghalia Indonesia.

v. Burke, G., 2006. Opportunities for Environmental Management in The Mining Sector in Asia (abstract). The Journal of Environment \& Development 15 (2): 224 - 235.

vi. Collier, P., 2010. The Political Economy of Natural Resources. Social Research Vol 77 : No. 4 : Winter 2010.

vii. Desvisa, S., M. Chaerul, E. Sembiring, 2014. Multi Kriteria Terhadap Pemilihan Sampah Organik Dengan Menggunakan Metode Analytical Network Process. Program Studi Magister Teknik Lingkungan, Fakultas Teknik Sipil dan Lingkungan. Institut Teknologi Bandung, Bandung.

viii. Dharmawan A.H., 2010. Mewujudkan Good Ecological Governance Dalam Pengelolaa Sumberdaya Alam. Pusat Studi Pembangunan Pertanian dan Perdesaan LPM-IPB, Bogor.

ix. Fauzi, A., 2014. Valuasi Ekonomi dan Penilaian Kerusakan Sumberdaya Alam dan Lingkungan. IPB Press, Bogor.

x. Frankel, J.A., 2012. The Natural Resouce Curse : A Survey of Diagnoses and Some Prescriptions. Faculty Research Working Paper Series. Harvard Kennedy School.John F. Kennedy School Goverment.

xi. Humpreys, M.J. D. Sach, dan J.E. Stiglitz, 2007. Apakah Masalah Kekayaan Sumberdaya Alam?, dalam Humpreys (editors): Escaping The Resource Curse. Columbia University Press. Columbia. p. 1-24.

xii. Iskandar R. Zainudin, Abd Hair Awang, Zaimah Ramli, Sarmila Md Sum and Meisanti., 2020. Effect of eviromental corporate social responsibility on enviromental well-being peception and the mediation role of community resilience. ERP Enviromental and John Wiley \& Sons Ltd.

xiii. Iskandar R. Zainudin, Abd Hair Awang and Zaimah Ramli., 2018. An anlysis of the community perceptions well-being (Special reference to nickel mining and processing industry. Management of Enviromental Quality: An International Journal. Emerald Publishing Limited 1477-7835.

xiv. Iswandi, R.M, La Ode Alwi, La Baco dan Lukman Yunus, 2018. Sustainable Mining Managemen. International Journal of Civil Engineering and Technology (IJCIET), Volume 9, Issue 10, October 2018, pp. 707-717.

xv. Iswandi, R.M., L. Yunus, L. Baco, E. Cahyono dan L. O. Alwi, 2015. Accesibilitas dan Region Economic Potential at Rapid Growth Stategi Area. Journal Avances in Enviromental Biologi 9(5) April 2015, pp. 5151-557

xvi. Iswandi, R. M., 2015. Natural Hazard Control in Sustainable Mining Development. Recent Advances on Enviromental and Life Science

xvii. Iswandi, R. M. dan L. O. Alwi, 2014. Kebijakan dan Strategi Pembangunan Pertambangan di Sekitar Kawasan Pertambangan Emas menuju Pembangunan Wilayah Tangguh dan Berkelanjutan. Prosiding Seminar Nasional ASPI, Pekanbaru, Riau.

xviii. Iswandi, R. M., L. O. Alwi dan I. Ido, 2014. Sustainable Mineral Mining Enviromental Managemen Model. Celebes International Conference on Eart Science (CICES), Kendari

xix. McMohan, G., E. R. Subdibjo, J. Aden, A. Bouzaher, G. Dore, and R.Kunanayagam, 2000. Mining and the Environment in Indonesia: Long-term Trends and Repercussions of the Asian Economic Crisis.Environment and Social Development Unit (EASES), East Asia and Pacific Region of the World Bank. Washington, DC

xx. Rijanta, R. dan M. Baiquni, 2003. Otonomi Daerah, Transisi Masyarakat dan Konflik Pengelolaan Sumberdaya (Pemahaman Teoritis dan Pemaknaan Empiris). Prosiding Lokakarya Nasional : Menuju Pengelolaan Sumberdaya Wilayah Berbasis Ekosistem Untuk Mereduksi Konflik Antar Daerah, Selenggarakan Fakultas Geografi Universitas Gadja Mada 30 Agustus 2003, Jogyakarta.

xxi. Rustiadi, E., S. Saefulhakim dan D. R. Panuju, 2011. Perencanaan Pengembangan Wilayah. Bogor. IPB Press.

xxii. Sachs, J.D. and A. Warner, 2001. "The Curse of Natural Resources." European Economic Review 45: 827-38.

xxiii. Sulistyani, A.T, 2004. Kemitraan dan Model-Model Pemberdayan. Yogyakarta: Guava Media

xxiv. Stiglitz, E. J., 2007. Making Globalization Work (Menyiasati Globalisasi Munuju Dunia yang Lebih Adil). Diterjemahkan Pada Penerbit Mizan Oleh Edrijani Azwaldi. PT. Mizan Pustaka, Bandung.

xxv. Williamson, O.E., 2000. The New Institutional Economics: Taking Stock, Looking Ahead. Journal of Economic Literature. Vol. 38, pp. 595-613.

xxvi. Yustika, E. 2012. Ekonomi Kelembagaan : Paradigma, Teori, dan Kebijakan. Jakarta. Penerbit Erlangga. 